\title{
Productivity and Resource Use in a Maize-Grain Legume Intercropping System in Punjab, Pakistan
}

\author{
Ayesha Ilyas ${ }^{1}$, Khalid Hussain ${ }^{1 *}$, Irshad bibi $^{2}$, Amina Ilyas ${ }^{3}$, Aftab Wajid ${ }^{1}$, Nasir Mehmood ${ }^{4}$, Riaz Ahmad ${ }^{1}$ and \\ Thomas Hilger ${ }^{5}$ \\ ${ }^{1}$ Department of Agronomy, University of Agriculture, Faisalabad, Pakistan \\ ${ }^{2}$ Instititute of Soil \& Environmental Sciences, University of Agriculture, Faisalabad, Pakistan \\ ${ }^{3}$ Department of Botany, Govt. College University, Lahore, Pakistan \\ ${ }^{4}$ Government College Women University, Faisalabad, Pakistan \\ ${ }^{5}$ Institute of Agricultural Sciences in the Tropics (Hans-Ruthenberg-Institute) (490), University of Hohenheim Stuttgart- \\ Germany \\ *For correspondence: khalid.hussain@uaf.edu.pk; khalidkhanuaf@gmail.com \\ Received 09 January 2021; Accepted 23 January 2021; Published 16 April 2021
}

\begin{abstract}
Intercropping is considered as an improved system of multiple cropping systems which safeguards crop stand and improves crop production. The main goal of intercropping is to produce high yield from piece of a land by judicious use of available resources which otherwise may not be exploited by a single crop. A study was executed to investigate productivity and resource use in a maize-grain legume intercropping at University of Agriculture, Faisalabad during 2017 and 2018. Experimental treatments included maize, mungbean, mash-bean, and cowpea monocultures (sole crops), and intercropping combinations of maize + mungbean, maize + mash-bean, and maize + cowpea. Highest maize grain yield was observed in maize sole cropping (6520 and $6813 \mathrm{~kg} \mathrm{ha}^{-1}$ ) and maize + mungbean intercropping (6375 and $6542 \mathrm{~kg} \mathrm{ha}^{-1}$ ) during 2017 and 2018 growing seasons, respectively. Maximum seed yield in grain legumes was observed in mung and mash bean sole cropping during both years. Land equivalent ratio (LER) was maximum in maize + cowpea (1.83 and 1.87) and maize + mungbean intercropping (1.77 and 1.80) during both years, respectively. Maximum net economic return (ER) of PKR 134158 $\mathrm{ha}^{-1}(\approx 900$ USD) was obtained from maize + mash bean intercropping system with highest benefit cost ratio (2.03) during 2017 while PKR 149358 ha $^{-1}(\approx 1003$ USD) along with benefit cost ratio (2.15) during 2018. Overall, LER and ER results indicated that maize-grain legume intercropping systems were beneficial in terms of land resource utilization and economic returns. The maize-grain legume intercropping systems are more sustainable option for small land-holding farmers in Pakistan. (C) 2021 Friends Science Publishers
\end{abstract}

Keywords: Cropping systems; Growth analysis; Crop productivity analysis; Resource use; Economic analysis

\section{Introduction}

Maize (Zea mays L.) is ranked third after wheat (Triticum aestivum L.) and rice (Oryza setiva L.) amongst the various food grain crops grown in Pakistan and is an exhaustive crop (heavy soil nitrogen feeder). It is sown on 1.42 million hectares area with a total production of 7.24 million tons during 2019-20 in Pakistan (GOP 2019-20). Legumes are cultivated on approximately 1.28 million ha or $5.3 \%$ of total cropped area in Pakistan (GOP 2019-20). Pakistan imported 97,530 metric tons of pulses in March 2020, 25\% higher than March 2019 which was 78,091 metric tons (PBS 201920).

Pakistan is a low-income country with more than $60 \%$ of the population living on less than 2 US\$ per day (UNDP 2019). In Pakistan, $75 \%$ of the poor live in rural areas; most of them depend on agriculture for income (Ghafoor et al. 2010; UNDP 2019). Lack of seed for alternative crops, coupled with state regulations that prohibit increased land allocation to crops other than wheat, rice, cotton and maize, restrict access for farmers to new income opportunities. In Pakistan, small farms cover about half of the arable land and 93\% of all farmers are smallholders, highlighting the importance of smallholder farmers for rural income and food security (UNDP 2019; PBS 2019-20). Despite an increasing agricultural gross domestic product, rural poverty, especially among smallholders, is worsening (Qasim and Knerr 2013). Declining or stagnant smallholder farmer income leads to reduced investment in small farms, which in turn leads to further shrinking productivity, in the end risking both livelihoods and food security (Qasim and Knerr 2013).

To cite this paper: Ilyas A, K Hussain, I Bibi, A Ilyas, A Wajid, N Mehmood, R Ahmad, T Hilger (2021). Productivity and resource use in a maize-grain legume intercropping system in Punjab, Pakistan. Intl J Agric Biol 25:985-994 
Small land holding farmers of the Pakistan typically lack technologies to diversify their production. Hence, they depend on a narrow range of crops (cereals and/or cotton), which fetch low market prices and deplete nitrogen and organic matter in the soil. Farmers have limited access to rotational crops that could generate additional income and reverse the nutrient depletion of soils. Moreover, farmers are bound to cultivate exhaustive crops which are continuously depleting nitrogen and soil organic matter. Natural resource degradation, especially declining soil fertility, strains agricultural productivity in Pakistan (Irfan 2007; Qadir et al. 2009). Soils in Pakistan are generally deficient in nitrogen, and the organic matter content is only about $0.5 \%$, compared to the $1-4 \%$ that is usually found in arable land (Shah and Arshad 2006). Farmers of these regions find themselves fully trapped in production systems that are unsustainable and unprofitable which directly increasing poverty of the region. Low soil fertility, erratic rainfall and improper fertilization are also increasing the risks of crop failure under sole cropping systems especially for small holding farmers in Pakistan. Intercropping can be helpful to overcome the risk of crop failure under such conditions. Intercropping is the simultaneous or sequential planting of two or more than two crops species on same piece of land with specific objective (Willey 1990) by safeguarding each other production even in case one crop failed to produce, the other provides food for the farm household (Rusinamhodzi et al. 2012).

Chickpea (Cicer arietinum L.), mungbean [Vigna radiate (L.) Wilczek] and mash beans (Vigna mungo L. Hepper) are the major legumes grown in Pakistan with various objectives. Grain legumes inclusion in the cropping system is not only essential for sustainability of soil fertility by fixing atmospheric nitrogen but also enrich the food chain (Giller 2001; Haider et al. 2020). Grain legume intercropping is considered as an effective and the most potential way to increase crop production particularly for small land holding farmers and food security (Silberg et al. 2017). Proper knowledge on ecological and economic performance of the intercropping system in relation to sole crops is most important. A feasible and or economically viable intercropping system development solely depends on proper selection of compatible crop species along with proper planting patterns. Crops which do not compete, differ in growth habits, duration and water requirements may make better use of resources under intercropping conditions. A combined crop canopy may utilize sunlight, water, nutrient in a better way as compared to sole cropping. Intercropping systems having legumes as intercrop may also provide nutritive advantages to the associated non-legume crop and enhance the overall farm productivity, rich the food chain and reduce import bill (Saleem et al. 2015).

Pulses like mungbean, mash, cowpea are part of daily cuisine in Pakistan and have high market demand. These pulses are now being considered as high value crops. In this study, we hypothesized that maize intercropping with grain legumes can enhance the productivity of small land holding due to efficient use of available resources along-with soil fertility improvement and high economic returns. The study was executed under field conditions with the following objectives (i) To enhance the production sustainability of maize based cropping system with the addition of legume crops, (ii) productivity evaluation of intercropping vs sole cropping (iii) to evaluate best possible options of maize grain legume intercropping in term of farm income sustainability for small land holding farmers.

\section{Materials and Methods}

\section{Study site}

This experiment was conducted at Agronomy Research Farm, University of Agriculture, Faisalabad central PunjabPakistan (N 31 ${ }^{\circ} 25^{\prime}$ 46.8048", E 73 4' 14.3112") during 2017 and 2018. According to Pakistan soil classification, Lyallpur soil series persist in the study area. The soil samples from $0-15 \mathrm{~cm}$ were randomly collected from the intercropping systems before and after the experiments and analyzed for physio-chemical properties (Table 1). The study site features semi-arid climatic conditions according to Köppen-Geiger classification with very hot and humid summers and dry cool winters. Maximum temperature is up to $46^{\circ} \mathrm{C}$ while minimum average temperature is about $4^{\circ} \mathrm{C}$ during winter. The study site is in center of Punjab-Pakistan. Wheat, sugarcane (Saccharum officinarum), cotton (Gossypium hirsutum) and maize are the main crops of this area.

\section{Experimental details}

Maize was intercropped with mungbean, mash bean and cowpea (Cicer arietinum L.), and sole cropping of all these crops i.e., maize, mungbean, mash bean and cowpea were maintained as controls. Maize hybrid 'TG46B90', mungbean cultivar 'AZRI 2011', mash bean cultivar 'Arooj 11 ', cowpea cultivar 'White Star' were used as test crop. Maize and legume seeds were obtained from Monsanto and AARI, Faisalabad, respectively. Randomized Complete Block Design (RCBD) having three replications with net plot size of $3.6 \mathrm{~m} \times 7 \mathrm{~m}$ was used for experimentation. Both year trials were carried out in the same experimental units, each treatment was repeated in the same plot in $2^{\text {nd }}$ year of the study. All the plantings were done in last week of June with hand drill during both years. Maize crop was planted at $60 \mathrm{~cm}$ distant rows while legume crops were sown with 30 $\mathrm{cm}$ row to row distance. Full dose of phosphorus (125 kg ha and $60 \mathrm{~kg} \mathrm{ha}^{-1}$ for maize and legume crops respectively) and potassium (125 kg ha-1 for maize only) was applied at the time of sowing. Nitrogen was applied in two splits by applying half at the time of planting while remaining half at 30-35 days after sowing. The sources of nitrogen, phosphorous and potassium were urea, DAP and SOP. The 
first irrigation was applied after crop emergence, second at blooming while third at the time grain development. Hand weeding was used to control the weeds. Both crops were harvested when $90 \%$ of cob and pods reached to maturity. The crop was kept securely into bundles and kept for drying until it reached $12 \%$ moisture level.

\section{Yield and related traits}

For calculation of yield related parameters, 10 plants were randomly selected from each treatment per replication just before harvest. All the cobs/pods collected from each crop were threshed from respective plots individually, no. of grains per cob and pod were counted, weighed after sundrying. Thereafter, 1000 grains/seeds wight from each treatment per replication was also recorded and averaged. Grain/seed yield from all the treatments with individual crops from all replications were collected and kept separately and thereafter the averages per crop per plot were taken and converted into $\mathrm{kg} \mathrm{ha}^{-1}$. All the dried stalks with cob and pods from each plot were harvested separately, weighed and average weights in each crop were taken on plot basis and then were converted into $\mathrm{kg} \mathrm{ha}^{-1}$.

\section{Growth and development}

Just after crop establishment, $30 \mathrm{~cm}$ of crop row was harvested from each plot with 30 days interval during the crop growing season. Moreover, sample fresh weight was measured just after the harvest. After fresh weight, plant samples were separated into leaf, stem, flower, cob and pods and each component weight were recorded with electric balance. Sub-samples were taken for further measurements. These sub-samples were then sun dried first and thereafter oven dried at $70^{\circ} \mathrm{C}$ till constant weight was attained. From the fresh leaves, $10 \mathrm{~g}$ sub-sample was taken for leaf area measurements. Following parameters were measured during the crop growing season:

Leaf area index is the projected area of leaves over a unit of land. Each crop LAI was measured with formula given by Watson (1952) along with crop growing season

$$
\text { Leaf Area Index }=\frac{\text { Leaf Area of the crop }}{\text { Crop covered area }}
$$

Leaf area duration (LAD) of each crop was measured along the growing season with following formula as estimated by Hunt (1978):

$$
L A D=\frac{(\text { Leaf area index }(L A I) 1+\text { Leaf area index }(L A I) 2) \times(\text { Time of LAI } 2-\text { Time of } L A I 1)}{2}
$$

Crop growth rate (CGR) $\left(\mathrm{g} \mathrm{m}^{-2} \mathrm{~d}^{-1}\right)$ was calculated for each crop during the growing season with the Hunt (1978) formula:

$$
C G R=\frac{T D W 2-T D W 1}{T 2-T 1}
$$

Where $\mathrm{TDW}_{1}$ and $\mathrm{TDW}_{2}$ are the sample total dry weights at times $\mathrm{T}_{1}$ and $\mathrm{T}_{2}$, respectively.
Net assimilation rate (NAR) $\left(\mathrm{g} \mathrm{m}^{-2} \mathrm{~d}^{-1}\right)$ was calculated for each crop with the Hunt (1978) formula:

$$
N A R=\frac{\text { Total dry matter at final harvest }}{\text { leaf area duration }}
$$

The fraction of intercepted photosynthetically active radiations ( $\mathrm{PPAR}$ ) was calculated as

$$
f \mathrm{PAR}=1-\frac{P A R_{b c}\left(M J m^{-2}\right)}{P A R_{a c}\left(M J m^{-2}\right)}
$$

Where, PAR $_{a c}$ is PAR above crop canopy and PAR $\mathrm{P}_{\mathrm{bc}}$ is PAR below crop canopy (SunScan Canopy analyzer was used for PAR measurements above and below crop canopy during the cropping season).

\section{Productivity evaluation}

Crop Harvest index (HI) and Land equivalent ratios (LERs) were used for cropping systems' productivity analysis.

Harvest index (HI) was calculated as:

$$
H I=\frac{G Y\left(g m^{-2}\right)}{T D M\left(g m^{-2}\right)}
$$

Where, GY is the grain yield and TDM is the total dry mater of maize and legume cops at harvest.

Land equivalent ratios (LER) was calculated as:

$$
L E R=\frac{M G Y_{I}\left(k g h a^{-1}\right)}{M G Y_{S}\left(k g h a^{-1}\right)}+\frac{L G Y_{I}\left(k g h a^{-1}\right)}{L G Y_{S}\left(k g h a^{-1}\right)}
$$

Where, $\mathrm{MGY}_{\mathrm{I}}$ is the maize grain yield production under intercropping condition, $\mathrm{MGY}_{\mathrm{s}}$ is the maize grain yield in sole cropping, $\mathrm{LGY}_{\mathrm{I}}$ is legumes grain yield under intercropped condition and $\mathrm{LGY}_{\mathrm{s}}$ is legumes grain yield in sole cropping. Area corrected maize and legumes grain yield will be used for LER calculation.

\section{Economic analysis}

Economic analysis of the all the treatments studied were carried out as net return/profit and benefit cost ratio to estimate the economic profitability of all sole and intercropping systems.

$$
\begin{gathered}
N R\left(P K R h a^{-1}\right)=G R\left(P K R h a^{-1}\right)-P C\left(P K R h a^{-1}\right) \\
B C R=\frac{G R\left(P K R h a^{-1}\right)}{P C\left(P K R h a^{-1}\right)}
\end{gathered}
$$

Where, $N R$ is the Net Return, $G R$ is the Gross Return, $P C$ is Production Cost, $B C R$ is Benefit Cost Ratio.

The economic analysis was done in Pakistan Rupees (PKR). One US\$ was considered as equal to 149-150 PKR. Production cost and commodity prices were calculated as indicated by Agriculture Marketing Information Service (AMIS), Directorate of Agriculture (Economics \& Marketing) Govt. of Pakistan (details are provided as 
supplementary material). Maize, mungbean, mash bean and cow pea market prices were PKR 6000, 3781, 5391 and 3840 per $40 \mathrm{~kg}$.

\section{Statistical analysis}

Statistical analysis was done in statistical analysis software (S.A.S.), V-9.2 (S.A.S. Inc., U.S.A.) for analysis of variance (ANOVA). The randomized complete block design (RCBD) was used in the field study for both years. The pairwise comparison of treatments were done using Tukey's Honest Significant Difference test at $P=0.05$.

\section{Results}

\section{Growth}

All treatments showed similar trend of leaf area development throughout the growing period (Fig. 1). The leaf area of maize steadily increased with start of growing season, reached maximum during active growing period (60 days after planting) with a declining trend towards maturity. In case of grain legumes, LAI pattern was similar to that of maize during the whole growing season. The LAI in grain legumes steadily increased with the start of growing season, reached maximum at 75 days of planting, thereafter a decrease can be observed up-to maturity.

Maize above ground biomass production pattern was similar in all treatments (Fig. 2). Maize above ground biomass production was increased along with growing period. Maximum increase in above ground dry biomass was observed during the active growing period from 30 to 75 days after planting maize. Higher values of above ground biomass were observed in maize sole cropping system followed by maize + mungbean intercropping. Lowest maize above ground biomass was measured in maize + mash bean intercropping system. Above ground biomass in grain legumes was steadily increased with growing season. Above ground dry biomass production in mungbean, mash and cowpea planted in sole crop produced higher above ground biomass production as compared to their intercropping with maize.

The effect of various cropping systems was statistically significant on maize LAD (Table 2). Highest cumulative LAD (250.44 days) was measured in maize sole cropping while lowest cumulative LAD of 232.41 days was obtained from maize + cowpea intercropping. The table 2 also depict that variability in grain legumes cropping systems induced statistically significant effects on cumulative LAD. Maximum cumulative LAD of 190.44 days was observed in mungbean sole cropping. Lowest cumulative LAD (123.02 days) was observed in maize + cowpea intercropping which was statistically non-significant with maize+ mash intercropping. The mean maize crop growth rate was statistically non-significant during 2017 but was significant during 2018 (Table 2). During 2018, statistically highest value of CGR was obtained from maize + mungbean intercropping which was at par with maize + mash intercropping. There was no statistically significant difference in mean CGR of grain legumes during both years. Net assimilation rate in maize was not influenced statistically by various maize cropping systems (Table 2). Maize net assimilation rate on an average varied from 5.99 to $6.57 \mathrm{~g} \mathrm{~m}^{-2} \mathrm{~d}^{-1}$ with highest net assimilation rate $6.57 \mathrm{~g} \mathrm{~m}^{-2}$ $\mathrm{d}^{-1}$ in maize sole cropping while lowest in maize + mash intercropping system. In grain legumes, maximum net assimilation rate $2.44 \mathrm{~g} \mathrm{~m}^{-2} \mathrm{~d}^{-1}$ was measured in maize+ mungbean intercropping and was statistically significant with all other treatments except mash sole cropping. Minimum net assimilation rate $\left(1.79 \mathrm{~g} \mathrm{~m}^{-2} \mathrm{~d}^{-1}\right)$ was observed in cowpea sole cropping.

The variability in fraction of intercepted photosynthetically active radiations during both growing seasons was statistically significant (Table 2). During 2017, maximum PAR was intercepted in maize + mungbean intercropping while, minimum fraction of PAR was intercepted in maize sole cropping. During 2018 growing season, maize fraction of intercepted PAR was statistically similar in all the treatments. In legumes, maximum fraction of PAR was intercepted in all sole cropping treatments while lower values were observed in all the intercropped treatments during 2017. Moreover, similar trends of fraction of intercepted photosynthetically active radiations in legumes were observed during 2018 growing season.

\section{Yield and related parameters}

Effect of cropping systems was statistically significant on maize number of grains per cob during both years (Table 3). During 2017, highest number of maize grains per cob (412.02) was observed in maize +mung bean intercropping. Lowest number of grains per cob (408.47) where observed in maize+ mash bean intercropping. During 2018, maximum no. of grains per cob were observed in maize sole and maize + mungbean intercrop whereas minimum maize grain per cobs were observed in maize+ mash bean intercropping.

The Table 3 also depict that variability in grain legumes cropping systems induced statistically significant effects on production of number of seed per pod. Maximum number of seeds per pod (9.15) were observed in mungbean sole cropping which was statistically at par with cowpea sole cropping, maize + mungbean intercropping during both years. Lowest number of seeds per pod (6.02) was observed in maize + mash bean intercropping. There were no statistically significant differences in maize 1000-grain weight under various maize cropping systems during 2017 while influenced significantly during 2018 (Table 3). During 2018, maximum 1000-grain weight was observed in maize sole cropping while minimum maize 1000-grain weight was obtained in maize + cowpea intercropping. In grain legumes maximum thousand seed weight of $56.2 \mathrm{~g}$ 
Maize-grain Legume Intercropping System / Intl J Agric Biol, Vol 25, No 5, 2021

Table 1: Soil physiochemical properties of the study site before and after the experiments

\begin{tabular}{|c|c|c|c|c|c|c|c|}
\hline & Soil depth & $* \mathrm{pH}$ & $\begin{array}{l}* \mathrm{SOC} \\
\left(\mathrm{g} \mathrm{kg}^{-1}\right)\end{array}$ & $\begin{array}{l}* \text { Total N } \\
\left(\mathrm{g} \mathrm{kg}^{-1}\right)\end{array}$ & Extractable $\mathrm{P}\left(\mathrm{mg} \mathrm{kg}^{-1}\right)$ & Extractable $\mathrm{K}\left(\mathrm{mg} \mathrm{kg}^{-1}\right)$ & $\mathrm{BD}\left(\mathrm{g} \mathrm{cm}^{-3}\right)$ \\
\hline Before Experiment & $0-15 \mathrm{~cm}$ & 7.82 & 10.00 & 0.85 & 13.5 & 240.6 & 1.4 \\
\hline After Experiment & $0-15 \mathrm{~cm}$ & 7.92 & 11.28 & 0.98 & 14.0 & 239.6 & 1.4 \\
\hline
\end{tabular}
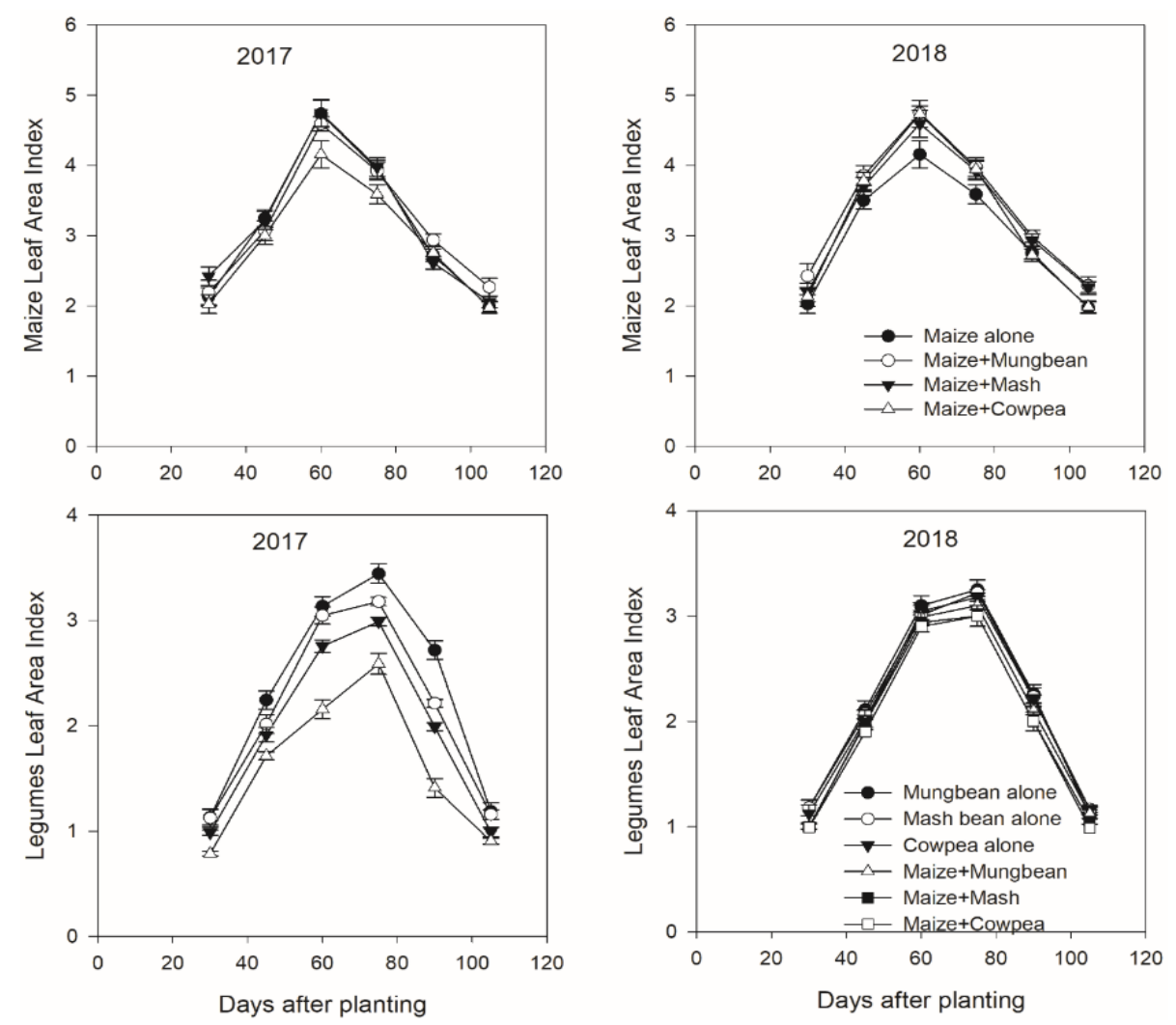

Fig. 1: Leaf area index development in maize and grain legumes under sole and intercropping cropping conditions during 2017 18 growing seasons

was observed in mung bean sole cropping and was statistically significant to all other treatments during 2017 while minimum thousand seed weight $(37.8 \mathrm{~g})$ was observed in maize + cowpea intercropping system. During 2018, maximum 1000 seed weight (57.3 g) was observed in mungbean sole cropping which was statistically significant than the rest of treatment.

Statistically significant differences in grain yield production were observed in all treatments during both years. During 2017, maximum grain yield of $6520 \mathrm{~kg} \mathrm{ha}^{-1}$ was observed in maize sole cropping while minimum maize grain yield of $5854 \mathrm{~kg} \mathrm{ha}^{-1}$ was recorded in maize + mash intercropping. Similar trends were observed during 2018. Grain yield production in legumes was statistically significant under sole and intercropping systems during both years. During 2017, maximum grain yield was observed in mungbean sole cropping (990.25 kg ha ${ }^{-1}$ ) while lowest grain yield of $708.01 \mathrm{~kg} \mathrm{ha}^{-1}$ was recorded in maize + cowpea intercropping. Moreover, during 2018, similar trends of grain yield production were observed in the grain legumes as observed during 2017 but there was an increase in the overall production. Maize biological yield was statistically significant during both cropping season (Table 3). In 2017, maximum biological yield of $16190 \mathrm{~kg} \mathrm{ha}^{-1}$ was recorded in maize sole cropping while minimum production (15091 kg ha ${ }^{1}$ ) was observed in maize + mash intercropping. Whereas during 2018, maximum maize biological yield was observed in maize sole cropping while lowest biological yield was observed in maize + cowpea intercropping. In legumes, maximum biological yield during 2017 was measured in mungbean sole cropping (3412 $\mathrm{kg} \mathrm{ha}^{-1}$ ), while lowest biological yield of $3001 \mathrm{~kg}$ ha ${ }^{1}$ was observed in maize + mash intercropping system. During 2018, all grain legume treatments planted as sole cropping systems showed statistically similar results in while lowest biological yield was observed in maize + mash intercropping which was also statistically at par with maize + cowpea intercropping. 
Ilyas et al. / Intl J Agric Biol, Vol 25, No 5, 2021

Table 2: Leaf area duration (LAD), mean crop growth rate (CGR), net assimilation rate (NAR) and fraction of intercepted radiation $(f$ IPAR) in maize and grain legumes under sole and intercropping conditions

\begin{tabular}{|c|c|c|c|c|c|c|c|c|}
\hline \multirow[t]{2}{*}{ Treatments } & \multicolumn{2}{|c|}{ LAD (days) } & \multicolumn{2}{|c|}{ Mean CGR $\left(\mathrm{g} \mathrm{m}^{-2} \mathrm{~d}^{-1}\right)$} & \multicolumn{2}{|c|}{$\operatorname{NAR}\left(\mathrm{g} \mathrm{m}^{-2} \mathrm{~d}^{-1}\right)$} & \multicolumn{2}{|c|}{$f$ IPAR $\left(\mathrm{MJ} \mathrm{m}^{-2}\right)$} \\
\hline & Maize & Legumes & Maize & Legumes & Maize & Legumes & Maize & Legumes \\
\hline \multicolumn{9}{|l|}{2017} \\
\hline Maize sole cropping & $250.44 \mathrm{a}$ & - & 17.07 & - & 5.68 & - & $0.81 \mathrm{~b}$ & - \\
\hline Mungbean sole cropping & - & $190.44 \mathrm{a}$ & - & 3.77 & - & $2.44 \mathrm{a}$ & - & $0.84 \mathrm{a}$ \\
\hline Mash sole cropping & - & $175.59 \mathrm{~b}$ & - & 3.90 & - & $2.29 \mathrm{a}$ & - & $0.85 \mathrm{a}$ \\
\hline Cowpea sole cropping & - & $173.86 \mathrm{~b}$ & - & 3.47 & - & $1.79 \mathrm{~b}$ & - & $0.84 \mathrm{a}$ \\
\hline Maize + mungbean & $251.14 \mathrm{a}$ & $159.52 \mathrm{c}$ & 17.83 & 3.67 & 6.39 & $1.95 \mathrm{~b}$ & $0.94 \mathrm{a}$ & $0.73 \mathrm{~b}$ \\
\hline Maize + mash bean & $251.87 \mathrm{a}$ & $130.67 \mathrm{~d}$ & 17.52 & 3.59 & 6.33 & $1.93 \mathrm{~b}$ & $0.93 \mathrm{a}$ & $0.72 \mathrm{~b}$ \\
\hline Maize+ Cowpea & $232.41 \mathrm{~b}$ & $123.02 \mathrm{~d}$ & 17.70 & 3.56 & 6.57 & $1.79 \mathrm{~b}$ & $0.92 \mathrm{ab}$ & $0.70 \mathrm{~b}$ \\
\hline$L S D$ & 2.53 & 8.02 & $N S$ & $N S$ & $N S$ & 0.20 & 0.11 & 0.10 \\
\hline \multicolumn{9}{|l|}{2018} \\
\hline Maize sole cropping & $268.08 \mathrm{~b}$ & - & $18.10 \mathrm{~b}$ & - & 6.77 & - & 0.88 & - \\
\hline Mungbean sole cropping & - & $199.05 \mathrm{a}$ & - & 4.52 & - & $2.59 \mathrm{a}$ & - & $0.88 \mathrm{a}$ \\
\hline Mash sole cropping & - & $189.25 \mathrm{a}$ & - & 4.19 & - & $2.86 \mathrm{a}$ & - & $0.80 \mathrm{ab}$ \\
\hline Cowpea sole cropping & - & $180.17 \mathrm{~b}$ & - & 4.49 & - & $1.99 \mathrm{~b}$ & - & $0.85 \mathrm{a}$ \\
\hline Maize + mungbean & $282.66 \mathrm{a}$ & $165.06 \mathrm{c}$ & $19.78 \mathrm{a}$ & 4.37 & 6.99 & $2.05 \mathrm{~b}$ & 0.92 & $0.76 \mathrm{~b}$ \\
\hline Maize + mash bean & $279.22 \mathrm{a}$ & $140.33 \mathrm{~d}$ & $18.88 \mathrm{ab}$ & 4.50 & 6.87 & $2.03 \mathrm{~b}$ & 0.94 & $0.73 \mathrm{~b}$ \\
\hline Maize+ Cowpea & $262.53 \mathrm{c}$ & $137.08 \mathrm{~d}$ & $18.72 b$ & 4.39 & 6.84 & $2.00 \mathrm{~b}$ & 0.94 & $0.73 \mathrm{~b}$ \\
\hline$L S D$ & 6.22 & 9.55 & 1.01 & $N S$ & $N S$ & 0.31 & $N S$ & 0.11 \\
\hline
\end{tabular}

Means followed by different small letters indicate significant differences between the treatments; $N S$ means non-significant differences
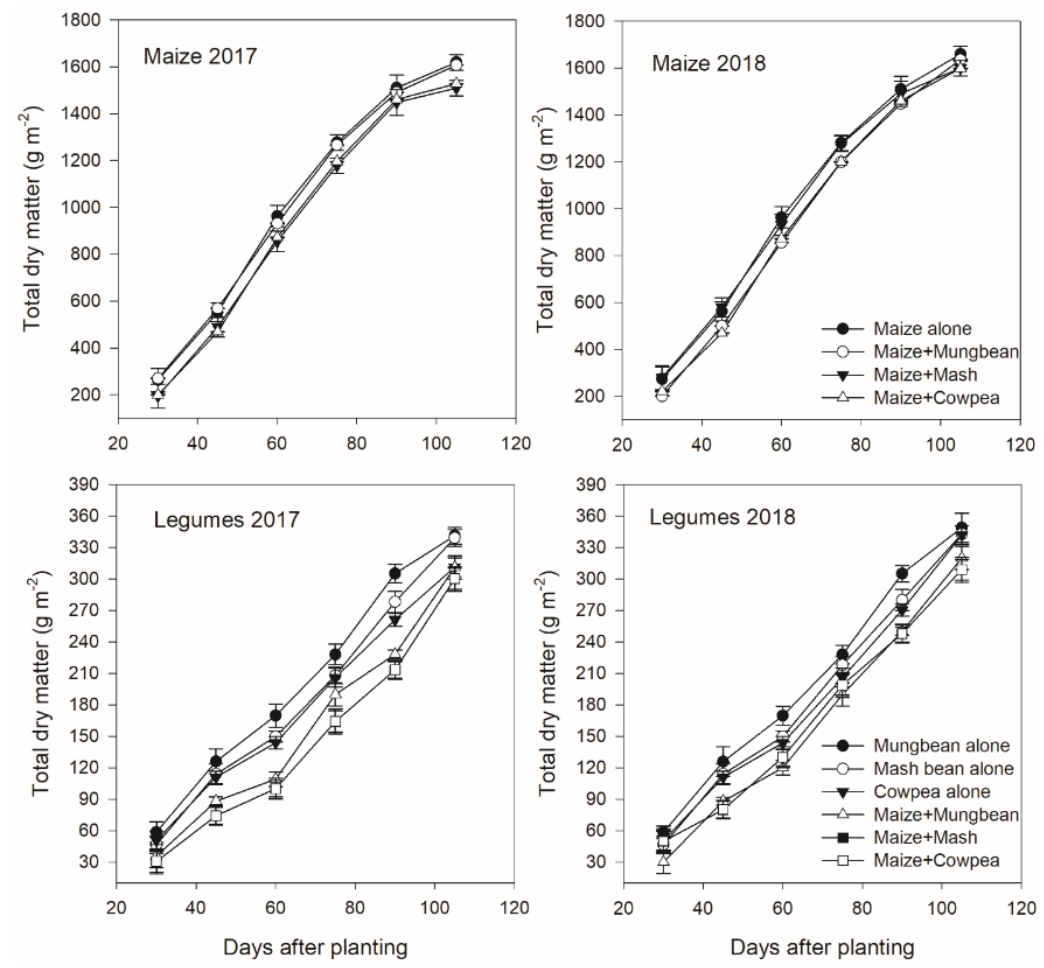

Fig. 2: Total biomass production in maize and grain legumes under sole and intercropping cropping conditions during 2017-18 growing seasons

\section{Productivity evaluation and economic analysis}

Harvest index of the treatment results showed statistically non-significant differences in maize planted under various cropping systems only in 2017 whereas, 2018 results showed statistically significant differences (Table 4). During 2018, statistically highest HI was observed in maize sole cropping which was statistically similar with maize + mungbean intercrop while minimum maize $\mathrm{HI}$ was observed in maize + mash intercropping which was also statistically at par with maize + cowpea intercropping. Grain legumes showed statistically significant differences in $\mathrm{HI}$ under sole and intercropping systems during both years. During 2017, the maximum value of harvest index (29.02\%) was recorded in mungbean sole cropping whereas statistically lowest harvest index (23.50\%) was observed in 
Maize-grain Legume Intercropping System / Intl J Agric Biol, Vol 25, No 5, 2021

Table 3: Yield and yield components of maize and grain legumes under sole and intercropping conditions

\begin{tabular}{|c|c|c|c|c|c|c|c|c|}
\hline \multirow[t]{2}{*}{ Treatments } & \multicolumn{2}{|c|}{ Number of grain/seeds per cobs/pods } & \multicolumn{2}{|c|}{ 1000-grain/seed weight $(\mathrm{g})$} & \multicolumn{2}{|c|}{ Grain yield $\left(\mathrm{kg} \mathrm{ha}^{1}\right)$} & \multicolumn{2}{|c|}{ Biological yield $\left(\mathrm{kg} \mathrm{ha}^{1}\right)$} \\
\hline & Maize & Legumes & Maize & Legumes & Maize & Legumes & Maize & Legumes \\
\hline \multicolumn{9}{|l|}{2017} \\
\hline Maize sole cropping & $411.36 \mathrm{a}$ & - & $255.2 \mathrm{a}$ & - & $6520 \mathrm{a}$ & - & 16190 a & - \\
\hline Mungbean sole cropping & - & $9.15 \mathrm{a}$ & - & $56.2 \mathrm{a}$ & - & $990.25 \mathrm{a}$ & - & $3412 \mathrm{a}$ \\
\hline Mash sole cropping & - & $6.55 \mathrm{c}$ & - & $42.9 \mathrm{~b}$ & - & $908.91 \mathrm{a}$ & - & 3391 a \\
\hline Cowpea sole cropping & - & $8.11 \mathrm{a}$ & - & $44.6 \mathrm{~b}$ & - & $760.26 \mathrm{~b}$ & - & $3111 \mathrm{~b}$ \\
\hline Maize + mungbean & $412.02 \mathrm{a}$ & $8.80 \mathrm{a}$ & $250.1 \mathrm{a}$ & $46.4 \mathrm{~b}$ & $6375 \mathrm{a}$ & $790.76 \mathrm{~b}$ & $16071 \mathrm{a}$ & $3109 \mathrm{~b}$ \\
\hline Maize + mash bean & $408.47 \mathrm{~b}$ & $6.02 \mathrm{c}$ & $240.7 \mathrm{~b}$ & $38.0 \mathrm{c}$ & $5854 \mathrm{~b}$ & $712.50 \mathrm{~b}$ & $15091 \mathrm{~b}$ & $3001 \mathrm{c}$ \\
\hline Maize+ Cowpea & $409.70 \mathrm{~b}$ & $7.68 \mathrm{ab}$ & $233.6 \mathrm{c}$ & $37.8 \mathrm{c}$ & $5900 \mathrm{~b}$ & $708.01 \mathrm{~b}$ & $15280 \mathrm{~b}$ & $3012 \mathrm{c}$ \\
\hline$L S D$ & 1.50 & 1.10 & 0.70 & 4.60 & 320 & 112.1 & 465 & 83 \\
\hline \multicolumn{9}{|l|}{2018} \\
\hline Maize sole cropping & $422.05 \mathrm{a}$ & - & $278.3 \mathrm{a}$ & - & $6813 \mathrm{a}$ & - & $16600 \mathrm{a}$ & - \\
\hline Mungbean sole cropping & - & $9.15 \mathrm{a}$ & - & $57.3 \mathrm{a}$ & - & $1033.1 \mathrm{a}$ & - & 3499 a \\
\hline Mash sole cropping & - & $7.59 \mathrm{~b}$ & - & $43.6 \mathrm{~b}$ & - & $925.65 \mathrm{a}$ & - & $3433 \mathrm{a}$ \\
\hline Cowpea sole cropping & - & $9.01 \mathrm{a}$ & - & $45.3 \mathrm{~b}$ & - & $800.01 \mathrm{~b}$ & - & $3420 \mathrm{a}$ \\
\hline Maize + mungbean & $420.18 \mathrm{a}$ & $8.89 \mathrm{a}$ & $269.6 \mathrm{a}$ & $47.0 \mathrm{~b}$ & $6542 \mathrm{a}$ & $823.66 \mathrm{~b}$ & $16368 \mathrm{a}$ & $3196 \mathrm{~b}$ \\
\hline Maize + mash bean & $417.40 \mathrm{c}$ & $7.16 \mathrm{~b}$ & $259.3 \mathrm{~b}$ & $43.0 \mathrm{~b}$ & $6019 b$ & $790.12 b$ & $16000 \mathrm{ab}$ & $3089 \mathrm{c}$ \\
\hline Maize + Cowpea & $419.70 \mathrm{ab}$ & $7.56 \mathrm{~b}$ & $238.9 \mathrm{c}$ & $40.9 \mathrm{~b}$ & $6101 \mathrm{~b}$ & $789.25 \mathrm{~b}$ & 15990 b & $3100 \mathrm{c}$ \\
\hline$L S D$ & 2.00 & 1.22 & 10.01 & 7.85 & 410 & 105.45 & 370 & 94 \\
\hline
\end{tabular}

Means followed by different small letters indicate significant differences between the treatments

maize + cowpea intercrop. Similar trends were observed during 2018.

Land equivalent ratio showed statistically significant differences among various treatments (Table 4). During 2017, highest land equivalent ratio of 1.83 was recorded in maize + cowpea intercropping followed by maize + mungbean intercrop (1.77). While during 2018, highest LER (1.87) was observed in maize + cowpea intercropping followed by maize + mungbean intercrop (1.80). Lowest LER values were obtained from sole cropping systems during both years of the study.

The crops planted in intercropping systems provided greater economic returns as compared to their sole cropping systems (Table 5). All intercropping systems showed higher net returns during both growing seasons. Highest net return of PKR 134158 (900 USD) was obtained from maize + mash bean intercropping system while lowest net return of PKR 24863 (USD) was obtained from cow pea sole cropping system during 2017. Among the intercropping treatments, minimum net return of PKR 107417 (167 USD) was observed from maize + cowpea intercropping system during 2017. Net return was increased from 2017 to 2018 growing season. The intercropping systems also showed higher net returns during 2018 growing season. Highest net return of PKR 149353 (1003 USD) was obtained from maize + mash bean intercropping system while lowest net return of PKR 28679 (193 USD) was obtained from cowpea sole cropping system during 2018. Among the intercropping treatments, minimum net return of PKR 120960 (812 USD) was observed from maize + cowpea intercropping system during 2018. Benefit cost ratio (BCR) results showed that the maximum BCR (2.02) was obtained from maize + mash bean intercropping system (T6) while minimum BCR value of 1.49 was observed in maize sole cropping system during 2017 growing conditions. The
$\mathrm{BCR}$ value remained more than 1.49 in all the treatments during 2017. The BCR results of 2018 showed that the maximum benefit cost ratio of 2.15 was obtained from maize + mash bean intercropping system closely followed by maize + mungbean intercropping with $\mathrm{BCR}$ value of 2.04. Minimum BCR (1.56) was also observed in maize sole cropping.

\section{Discussion}

Maize LAI was higher under intercropping systems because maize utilizes the available plant resources efficiently than the grain legume to develop the leaf area and enhance PAR interception (Kamara et al. 2019). Higher LAI can improve the efficiency of PAR interception which ultimately regulate the photosynthesis and yield development (Yin et al. 2003). The lower values of LAI, LAD, mean CGR, NAR and $f$ IPAR in the grain legumes under intercropping systems may be due to above (light) and below ground (water and nutrient) competition with taller maize plants (Muneer et al. 2004; Kamara et al. 2019). Higher maize dry matter production in sole cropping system was possibly due more area under maize crop whereas higher amount of dry matter production in grain legumes under sole cropping systems was due to higher resource availability as compared to intercrop treatments where maize induced shading effect on the grain legumes. The final grain yield of a crop is a function of combined effects of all the yield components, the cropping condition, available resources, and the environmental conditions of the area. Grain yield of legume crops was slightly lower in intercropped systems may be due to competition of resources especially for light due to shading effect of maize. Maize higher number of grains per cob is possibly due to availability of more nutrients under intercropping systems supplied by the grain legumes as they biological 
Ilyas et al. / Intl J Agric Biol, Vol 25, No 5, 2021

Table 4: Productivity evaluation of maize and grain legumes under sole and intercropping conditions

\begin{tabular}{|c|c|c|c|}
\hline \multirow[t]{2}{*}{ Treatments } & \multicolumn{2}{|c|}{ Harvest index (\%) } & \multirow[t]{2}{*}{ Land equivalent ratio } \\
\hline & Maize & Legumes & \\
\hline 2017 & & & \\
\hline Maize sole cropping & 40.27 & - & $1.00 \mathrm{c}$ \\
\hline Mungbean sole cropping & - & $29.02 \mathrm{a}$ & $1.00 \mathrm{c}$ \\
\hline Mash sole cropping & - & $26.80 \mathrm{~b}$ & $1.00 \mathrm{c}$ \\
\hline Cowpea sole cropping & - & $24.44 \mathrm{bc}$ & $1.00 \mathrm{c}$ \\
\hline Maize + mungbean & 39.66 & $25.43 \mathrm{~b}$ & $1.77 \mathrm{a}$ \\
\hline Maize + mash bean & 38.79 & $23.74 \mathrm{c}$ & $1.68 \mathrm{~b}$ \\
\hline Maize + Cowpea & 38.61 & $23.50 \mathrm{c}$ & $1.83 \mathrm{a}$ \\
\hline$L S D$ & $N S$ & 1.40 & 0.09 \\
\hline \multicolumn{4}{|l|}{2018} \\
\hline Maize sole cropping & $41.04 \mathrm{a}$ & - & $1.00 \mathrm{~b}$ \\
\hline Mungbean sole cropping & - & $29.52 \mathrm{a}$ & $1.00 \mathrm{~b}$ \\
\hline Mash sole cropping & - & $26.96 \mathrm{~b}$ & $1.00 \mathrm{~b}$ \\
\hline Cowpea sole cropping & - & $23.39 \mathrm{~b}$ & $1.00 \mathrm{~b}$ \\
\hline Maize + mungbean & $39.97 \mathrm{a}$ & $25.77 \mathrm{~b}$ & $1.80 \mathrm{a}$ \\
\hline Maize + mash bean & $37.62 \mathrm{~b}$ & $25.58 \mathrm{~b}$ & $1.70 \mathrm{~b}$ \\
\hline Maize + Cowpea & $38.15 \mathrm{~b}$ & $25.46 \mathrm{~b}$ & $1.87 \mathrm{a}$ \\
\hline$L S D$ & 1.78 & 2.01 & 0.07 \\
\hline
\end{tabular}

Table 5: Economic analysis maize and grain legumes under sole and intercropping conditions during 2017 and 2018 cropping seasons

\begin{tabular}{|c|c|c|c|c|c|c|}
\hline Treatments & Maize return $\left(\right.$ Rs. ha $\left.{ }^{-1}\right)$ & Legume return (Rs. ha $\left.{ }^{-1}\right)$ & Gross return (Rs. ha $\left.{ }^{-1}\right)$ & Production cost (Rs. ha $\left.{ }^{-1}\right)$ & Net return* & $\mathrm{BCR}$ \\
\hline \multicolumn{7}{|l|}{2017} \\
\hline Maize sole cropping & 187254 & - & 187254 & 125458 & 61796 (415) & 1.49 \\
\hline Mungbean sole cropping & - & 93608 & 93608 & 48290 & $45318(304)$ & 1.94 \\
\hline Mash sole cropping & - & 122502 & 122503 & 48122 & 74381 (499) & 2.55 \\
\hline Cowpea sole cropping & - & 72985 & 72985 & 48122 & $24863(167)$ & 1.52 \\
\hline Maize + mungbean & 183090 & 74331 & 257421 & 130000 & $127421(855)$ & 1.98 \\
\hline Maize + mash bean & 168127 & 96030 & 264158 & 130000 & $134158(900)$ & 2.03 \\
\hline $\begin{array}{l}\text { Maize + Cowpea } \\
2018\end{array}$ & 169448 & 67969 & 237417 & 130000 & $107417(721)$ & 1.83 \\
\hline Maize sole cropping & 195669 & - & 195669 & 125458 & $70211(471)$ & 1.56 \\
\hline Mungbean sole cropping & - & 94573 & 94573 & 48290 & $46283(311)$ & 1.96 \\
\hline Mash sole cropping & - & 124759 & 124759 & 48122 & $76637(515)$ & 2.59 \\
\hline Cowpea sole cropping & - & 76801 & 76801 & 48122 & 28679 (193) & 1.60 \\
\hline Maize + mungbean & 187886 & 77424 & 265310 & 130000 & $135310(908)$ & 2.04 \\
\hline Maize + mash bean & 172866 & 106492 & 279358 & 130000 & $149358(1003)$ & 2.15 \\
\hline Maize + Cowpea & 175192 & 75768 & 250960 & 130000 & $120960(812)$ & 1.93 \\
\hline
\end{tabular}

*The net return values present in parenthesis are $\mathrm{USD} \mathrm{ha}^{-1}(1 \mathrm{USD}=149 \mathrm{PKR})$ while outside parenthesis are Rs. ha ${ }^{-1}$

$\mathrm{BCR}$ is benefit cost ratio

fix the nitrogen (Rusinamhodzi et al. 2012; Khan et al. 2012). Moreover, thousand grain/seed weight reveals the magnitude of grain/seed development which reflects the final production of the crop. Grain legumes planted as sole cropping may be faced less resources competition especially for light and produced healthy grains and overall high grain yield during both years. These findings are in accordance with the findings of Khan et al. (2012) who observed the significant differences in grain legumes 1000seed weight planted under various intercropping systems. Earlier research under similar condition also pointed similar trends in the results (Ullah et al. 2007; Khan et al. 2012). Moreover, maize-grain legume intercropping benefits are achieved as total yield of crops both legume and maize (Maitra et al. 2020).

The physiological efficiency and ability of a crop plant to convert the dry matter into grain/economic yield can be assessed by its harvest index (HI) value. The higher the value of HI, the more grain yield production per unit of dry matter. This indicates the similarity in physiological ability of maize to transform dry matter into grain yield under sole and intercrop systems. Maize harvest index was not significant for first year indicating same behavior of maize to convert the dry matter into economic yield in all cropping systems. two consecutive year planting of grain legume changed the HI values of maize with the passage of time which was indicated by $\mathrm{HI}$ values of $2^{\text {nd }}$ year. Land equivalent ratio is the relative land area under sole crop that is required to produce the yields achieved in the intercropping, keeping the management same for intercropping and sole cropping. Moreover, all the intercropping treatments showed land equivalent ratio's more than 1 and LER more than one was indication of yield advantage over the sole cropping systems. This was attributed to a judicious utilization of water, light and nutrients for plant growth under intercropping systems. Land equivalent ratios of all intercropping system varied from 1.68 to 1.83 in 2017 and 1.70 to 1.87 in 2018, 
indicating a better land utilization along with available resources under intercropping conditions than that of sole cropping systems (Kamara et al. 2019). This means 68 to $83 \%$ and 70 to $87 \%$ extra land is required by sole cropping system to attain yield equal to intercropping system (Agegnehu et al. 2006; Dhimam et al. 2007; Bedoussac and Justes 2010).

Modern agriculture around the globe is focused on economics. The sustainable production and economic profitability gains are more important when the land holding is small. In Pakistan, small farms cover about half of the arable land and $93 \%$ of all farmers are smallholders, highlighting the importance of smallholder farmers for rural income and food security (UNDP 2019; PBS 2019-20). Maize grain legumes intercropping increased farm income as compared to sole cropping systems due to better market incentives for grain legumes. Earlier studies carried out in various environments also mentioned superiority of maize grain-legume intercropping in raising farm income and soil fertility restoration than the mono/sole cropping of the component crops (Ondurua and Preez 2007; Ullah et al. 2007; Saleem et al. 2015). High net returns were obtained from maize + mash bean and maize + mungbean intercropping system during both years. Mash and mungbean are an important part of daily cuisines and the protein quality obtained from them is superior to that of wheat, particularly in amino acid such as threonine, tryptophan, and lysine. Mash is the highest market value pulse crop in Pakistan due to its high consumption that increased the net return of maize + mash bean intercropping system. High market prices of mash and market driven demand of mash can provide an option for the farmers to raise their farm income and livelihood. Declining or stagnant smallholder farmer income leads to reduced investment in small farms, which in turn leads to further shrinking productivity, in the end risking both livelihoods and food security (Qasim and Knerr 2013). Crop diversification using grain legumes has proven potential to provide both additional incomes to farmers and improved soil fertility (Shanmugasundaram et al. 2009) which was clearly indicated from the economic analysis of current study.

\section{Conclusion}

Maize-grain legumes intercropping systems proved to more productive cropping systems as compared to sole cropping. Intercropping systems exploited the available resources judiciously which led to a higher grain and biomass yield. Maize + mash bean intercropping system would be a viable solution for small land holding farmers to raise their farm income with sustainable production. Introduction of high yielding grain legume cultivars can further strengthen these intercropping systems. Grain legumes intercropping with other main crops like wheat, sugarcane can be focused on future research to widen the cropping system choice of small landholding farmers.

\section{Acknowledgements}

Authors are thankful to Higher education commission of Pakistan for funding the research.

\section{Author Contributions}

AI, KH, IB, AW, RA planned the experiments, AI, KH, RA conducted experiments, AI, KH, NM and TH interpreted the results and made the writeup.

\section{Conflicts of Interest}

All other authors declare no conflicts of interest.

\section{Data Availability}

Data presented in this study are available on fair request to the corresponding author.

\section{Ethics Approval}

Not applicable.

\section{References}

Agegnehu G, A Ghizaw, W Sinebo (2006). Yield performance and land-use efficiency of barley and faba bean mixed cropping in Ethiopian highlands. Eur J Agron 25:202-207

Bedoussac L, E Justes (2010). Dynamic analysis of competition and complementarity for light and $\mathrm{N}$ use to understand the yield and the protein content of a durum wheat-winter pea intercrop. Plant Soil 330:37-54

Dhimam KV, AS Lithourgidis, IB Vasilakoglou, CA Dordas (2007). Competition indices of common vetch and cereal intercrops in two seeding ratio. Field Crops Res 100:249-256

Ghafoor A, M Hussain, K Naseer, M Ishaque, MH Baloch (2010). Factors affecting income and saving of small farming households in Sargodha District of the Punjab, Pakistan. Intl Busin Econ Res J 26:27-35

Giller KE (2001). Nitrogen Fixation in Tropical Cropping Systems. CABI Publishing, Wallingford, UK

GOP (2019-20). Agricultural Statistics of Pakistan. Government of Pakistan

Haider MU, M Hussain, M Farooq, A Nawaz (2020). Zinc nutrition for improving the productivity and grain biofortification of mungbean. $J$ Soil Sci Plant Nutr 20:1321-1335

Hunt R (1978). Plant Growth Analysis. Edward Arnold, London, UK

Irfan M (2007). Poverty and natural resource management in Pakistan. Pak Dev Rev 46:691-708

Kamara A, A Tofa, T Ademulegun, R Solomon, H Shehu, N Kamai, L Omoigui (2019). Maize-soybean intercropping for sustainable intensification of cereal-legume cropping systems in northern Nigeria. Exp Agric 55:73-87

Khan M, K Naveed, K Ali, B Ahmad, S Jan (2012). Impact of mungbeanmaize intercropping on growth and yield of mungbean. Pak J Weed Sci Res 8:191-200

Maitra S, T Shankar, P Banerjee (2020). Potential and advantages of maizelegume intercropping system. In: Maize-Production Use. IntechOpen, London, UK

Muneer AP, HM Fida, AK Mumtaz, IS Muhammad (2004). Performance of maize in intercropping system with soybean under different patterns and nitrogen levels. J Appl Sci 4:201-205 
Ilyas et al. / Intl J Agric Biol, Vol 25, No 5, 2021

Ondurua DD, CCD Preezb (2007). Ecological and agro-economic study of small farms in sub-Saharan Africa. Agron Sustain Dev 27:197-208

PBS - Pakistan Bureau of Statistics, Government of Pakistan, Islamabad (2019-20). http://www.pbs.gov.pk/content/agriculture-statistics

Qadir M, AD Noble, AS Qureshi, RK Gupta, T Yuldashev, A Karimov (2009). Salt-induced land and water degradation in the Aral Sea basin: A challenge to sustainable agriculture in Central Asia. Nat Res Forum 33:134-149

Qasim M, B Knerr (2013). Determinants of farm revenues from rainfed agriculture in the Punjab, Pakistan. Outl Agric 42:201-207

Rusinamhodzi L, M Corbeels, J Nyamangara, KE Giller (2012). Maizegrain legume intercropping is an attractive option for ecological intensification that reduces climatic risk for smallholder farmers in central Mozambique. Field Crops Res 136:12-22

Saleem R, ZI Ahmad, MA Anees, A Razzaq (2015). Productivity and land use efficiency of maize mungbean intercropping under different fertility treatments. Sarhad J Agric 31:37-44

Shah ZH, M Arshad (2006). Land Degradation in Pakistan: A Serious threat to environments and economic sustainability. Available at: http://www.eco-web.com/edi/060715.html
Shanmugasundaram S, JDH Keatinge, JDA Hughes (2009). The Mungbean transformation diversifying crops, defeating malnutrition. IFPRI Discussion Paper 00922. Available at: http://ebrary.ifpri.org/utils/ getfile/collection/p15738coll2/id/30176/filename/30177.pd

Silberg TR, RB Richardson, M Hockett, SS Snapp (2017). Maize-legume intercropping in central Malawi: determinants of practice. Intl $J$ Agric Sustain 15:662-680

Ullah A, AM Bhatti, A Gurmani, M Imran (2007). Studies on planting patterns of maize (Zea mays L.) facilitating legumes intercropping. $J$ Agric Res 45:113-118

UNDP - United Nations Development Program (2019). Human Development Report 2019, p:6. Available at: http://hdr.undp.org/sites/all/themes/hdr_theme/country-notes/PAK.pdf

Watson DJ (1952). The physiological basis of variation in yield. Adv Agron 4:101-145

Willey RW (1990). Resource use in intercropping systems. Agric Water Manage 17:215-231

Yin X, EA Lantinga, AH Schapendonk, X Zhong (2003). Some quantitative relationships between leaf area index and canopy nitrogen content and distribution. Ann Bot 9:893-903 